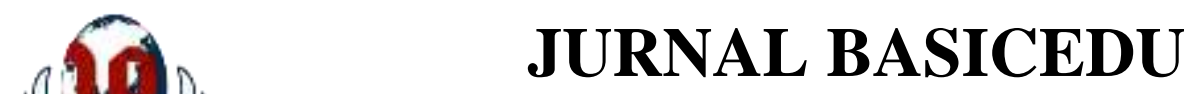

Volume 5 Nomor 5 Tahun 2021 Halaman 4026 - 4036

Research \& Learning in Elementary Education

https://jbasic.org/index.php/basicedu

PAHLATAM

\title{
Pengembangan Media Pembelajaran Berbasis Web untuk Meningkatkan Keterampilan Mahasiswa pada Mata Kuliah Pemrograman Web Dasar di STKIP Muhammadiyah Muara Bungo
}

\author{
Yogi Irdes Putra ${ }^{1 凶}$, Ahmad Ridoh $^{2}$ \\ Pendidikan Teknologi Informasi, STKIP Muhammadiyah Muara Bungo, Indonesia ${ }^{1,2}$ \\ E-mail: yogiip28@ gmail.com ${ }^{1}, \underline{\text { ridohadriati@gmail.com }}^{2}$
}

\begin{abstract}
Abstrak
Tujuan penelitian ini adalah: (1) Mengembangkan media pembelajaran berbasis web. (2) Mengetahui kelayakan media pembelajaran berbasis web melalui uji validitas, uji praktikalitas, dan uji efektifitas. Jenis penelitian pengembangan ini adalah Research and Develpoment dengan model pengembangan 4D (four-D), yaitu: (1) Define (pendefinisian) untuk menentukan dan menetapkan kebutuhan pengembangan. (2) Design (rancangan) memilih media, merancang dan membuat media. (3) Develop (pengembangan) melakukan uji validitas, praktikalitas, dan efektifitas. Validitas dilakukan oleh 6 orang validator, praktikalitas dilakukan oleh 2 orang dosen, dan efektifitas dilihat dari tes keterampilan pretest dan posttest. (4) Disseminate (penyebaran) dengan memasukkan media web pada salah satu webhosting di internet, mencobakan media pada aktivitas perkuliahan mahasiswa, dan mempromosikan kepada dosen-dosen dilingkungan prodi. Penelitian ini menghasilkan media pembelajaran berbasis web yang sudah melalui beberapa uji pegembangan, yaitu: (1) Uji validitas, hasil yang diperoleh sebesar 0,83 (aspek rekayasa perangkat lunak), 0,92 (aspek komunikasi visual), dan 0,88 (aspek pembelajaran) dengan kategori valid. (2) Uji praktikalitas, berdasarkan respon dosen diperoleh nilai presentase sebesar 88,92\% dan respon siswa diperoleh nilai persentase sebesar 84,31\% dengan kategori praktis. (3) Uji efektifitas, hasil tes yang diperoleh secara klasikal sudah mencapai $85 \%$ diatas kriteria ketuntasan menunjukkan peningkatan antara pretest dan posttest. Berdasarkan hasil uji yang diperoleh, dapat disimpulkan bahwa media pembelajaran berbasis web merupakan media yang valid, praktis, dan efektif.
\end{abstract}

Kata Kunci: media pembelajaran, web, pengembangan.

\begin{abstract}
The objectives of this research are: (1) Developing web-based learning media. (2) Knowing the feasibility of web-based learning media through validity testing, practicality testing, and effectiveness testing. The type of development research is Research and Development with a 4D (four-D) development model, namely: (1) Define to determine and determine development needs. (2) Design (design) select media, design and create media. (3) Develop (development) to test the validity, practicality, and effectiveness. Validity was carried out by 6 validators, practicality was carried out by 2 lecturers, and effectiveness was seen from the pretest and posttest skills tests. (4) Disseminate (disseminate) by including web media in one of the web hosting sites on the internet, testing the media on student lecture activities, and promoting it to lecturers in the study program environment. This research produces web-based learning media that has gone through several development tests, namely: (1) Validity test, the results obtained are 0.83 (software engineering aspect), 0.92 (visual communication aspect), and 0.88 (learning aspects) with valid categories. (2) Practicality test, based on the teacher's response, a percentage value of $88.92 \%$ was obtained and the student's response was a percentage value of $84.31 \%$ in the practical category. (3) The effectiveness test, the test results obtained classically have reached $85 \%$ above the completeness criteria showing an increase between pretest and posttest. Based on the test results obtained, it can be concluded that web-based learning media is a valid, practical, and effective media.
\end{abstract}

Keywords: learning media, web, development.

Copyright (c) 2021 Yogi Irdes Putra, Ahmad Ridoh

Corresponding author :

Email : yogiip28@gmail.com

DOI : https://doi.org/10.31004/basicedu.v5i5.1484

ISSN 2580-3735 (Media Cetak)

ISSN 2580-1147 (Media Online)

Jurnal Basicedu Vol 5 No 5 Tahun 2021

p-ISSN 2580-3735 e-ISSN 2580-1147 
4027 Pengembangan Media Pembelajaran Berbasis Web untuk Meningkatkan Keterampilan Mahasiswa pada Mata Kuliah Pemrograman Web Dasar di STKIP Muhammadiyah Muara Bungo - Yogi Irdes Putra, Ahmad Ridoh

DOI: https://doi.org/10.31004/basicedu.v5i5.1484

\section{PENDAHULUAN}

Inovasi teknologi memberikan implikasi luas dalam kehidupan termasuk dibidang pendidikan. Teknologi menuntut dunia pendidikan untuk selalu menyelaraskan perkembangan teknologi dengan kualitas pendidikan, terutama dalam pemanfaatannya pada proses pembelajaran (M. P. Rusman and Cepi 2012). Pemanfaatan perkembangan teknologi ini membutuhkan aplikasi atau program yang digunakan dalam penyampaian materi ajar kepada mahasiswa salah satunya yaitu media berbasis web. Media berbasis web dapat memberikan fleksibilitas belajar kepada mahasiswa untuk meningkatkan pemahaman dan keterampilan terhadap materi perkuliahan (Pratomo and Irawan 2015). Mata kuliah pemrograman web dasar menekankan pada kompetensi keahlian dalam pembuatan website. Keterampilan dalam pembuatan website sulit untuk dipahami oleh sebagian mahasiwa karena waktu pembelajaran yang tersedia dikelas sangat terbatas.

Adapun media penunjang dalam bentuk e-learning kampus, belum mampu memberikan kemudahan kepada mahasiswa untuk memahami materi pemrograman web dasar yang sifatnya praktek. Fitur yang terdapat pada e-learning kampus hanya beriisi konten teks dan gambar, kemudian tidak adanya fitur simulasi pembuatan dan pengkodean website. Secara umum materi keterampilan pada mata kuliah pemrograman web dasar cenderung membutuhkan perulangan untuk memahaminya, karena kemampuan masing-masing mahasiswa berbeda.

Keterampilan dalam pembuatan website sangat dibutuhkan saat ini, hal itu ditandai dengan banyaknya permintaan pekerja yang berkompeten dalam menciptakan suatu website di dunia usaha dan industri. Penggunaan media pembelajaran berbasis web juga diebut sebagai pembelajaran jarak jauh. Menurut UndangUndang 20 Tahun 2003 tentang sistem pendidikan nasional (SISDIKNAS), yang dimaksud dengan pendidikan jarak jauh adalah "Peserta didik terpisah dari pendidik dan pembelajarannya menggunakan berbagai sumber belajar melalui teknologi komunikasi, informasi dan media lainnya".

Penggunaan media pembelajaran berbasis web mendorong penyelenggaraan pendidikan semakin efektif (Darmansyah 2010). Dengan menggunakan media web memungkinkan banyaknya informasi data pembelajaran yang diperoleh, sehingga memberikan penjelasan kepada mahasiswa lebih lengkap.

Pembelajaran berbasis web (web based learning) adalah sistem pembelajaran yang memanfaatkan media elektronik (diarahkan pada penggunaan teknologi komputer dan internet) sebagai alat untuk membantu kegiatan pembelajaran (Daryanto 2013). Menurut (D. K. Rusman and Riyana 2011) perubahan akan tuntutan pengintegrasian teknologi dalam kegiatan pembelajaran menjadikan dunia pendidikan memerlukan inovasi dan kreativitas dalam proses pembelajaran, salah satunya yaitu dengan penggunaan media pembelajaran berbasis web dalam kegiatan belajar mengajar.

Berdasarkan uraian diatas maka penelitian ini penting dilaksanakan untuk mengembangkan media pembelajaran berbasis web terhadap keterampilan mahasiswa Prodi Pendidikan Teknologi Informasi STKIP Muhammadiyah Muara Bungo pada mata kuliah pemrograman web dasar. Media pembelajaran berbasis web yang akan dikembangkan digunakan sebagai penunjang kegiatan perkuliahan baik dikelas maupun diluar kelas (Putra 2017). Media pembelajaran berbasis web yang dihasilkan bersifat online serta memiliki fitur diskusi grup, simulasi dalam pengkodean web, dan dilengkapi dengan video-video materi pembelajaran. Selain itu, hasil penelitian ini dapat dijadikan sebagai referensi dalam mengembangkan media pembelajaran berbasis web.

\section{METODE}

Penelitian ini termasuk penelitian Research and Development $(R \& D)$ untuk mengembangkan dan menghasilkan produk-produk pendidikan berupa materi, media, alat evaluasi, dan sebagainya (Sugiyono 
4028 Pengembangan Media Pembelajaran Berbasis Web untuk Meningkatkan Keterampilan Mahasiswa pada Mata Kuliah Pemrograman Web Dasar di STKIP Muhammadiyah Muara Bungo - Yogi Irdes Putra, Ahmad Ridoh

DOI: https://doi.org/10.31004/basicedu.v5i5.1484

2010). Penelitian ini menggunakan model pengembangan 4D (four-D model). Proses pengembangan terdiri dari 4 tahap meliputi: tahap pendefinisian (define), tahap perancanaan (design), tahap pengembangan (develop), dan tahap penyebaran (disseminate) (Rukun and Irfan 2020).

1. Tahap Pendefinisian. Tahap ini bertujuan untuk menetapkan dan mendefinisikan masalah yang dihadapi dalam pembelajaran serta menganalisis kebutuhan mahasiswa. Tahap ini memiliki 3 langkah, yaitu:

a) Analisis ujung depan (studi lapangan). Dengan analisis ini akan didapatkan gambaran fakta, harapan dan alternatif penyelesaian masalah. b) Analisis mahasiswa, dilakukan untuk mengetahui karakteristik kepribadian mahasiswa serta kemampuan dalam menguasai materi perkuliahan. c) Analisis konsep. Dalam pelaksanaannya, analisis ini dilakukan untuk menentukan materi yang akan dicantumkan pada media web.

2. Tahap Perancangan. Pada tahap ini dilakukan langkah-langkah sebagai berikut : a) Pemilihan media. Media yang akan dikembangan yaitu media pembelajaran berbasis web yang berisi fitur video, forum diskusi realtime, simulasi praktek pengkodean website. b) Rancangan awal. Dibagi menjadi 2 tahapan yaitu, desain logis dan desain fisik. Hasil pembuatan desain logis ini adalah konteks diagram (context diagram), DFD (Data Flow Diagram) yang berfungsi untuk memudahkan pengguna memahami bagaimana media web yang dikembangkan berjalan serta mengetahui apa saja aktivitas yang dilakukan pengguna (Muhammad Hakiki 2021). Desain fisik bertujuan untuk merancang antarmuka atau tampilan pengguna dengan media web.c) Pembuatan media. Dilakukan untk memulai proses pembuatan media pembelajaran berbasis web dengan menggunakan aplikasi pendukung dan bahasa pemrograman. Aplikasi yang digunakan untuk membuat media pembelajaran berbasis web yaitu, Sublime Text, XAMPP, SQL, Adobe Photoshop, Bahasa pemrograman PHP, CodeIgniter dan JavaScript (Darmawiguna 2013).

3. Tahap Pengembangan, meliputi tahap validasi, uji praktikalitas, dan uji efektivitas. Adapun tujuannya untuk menghasilkan media pembelajaran berbasis web yang valid, praktis, dan efektif. Pada tahapan ini juga dilakukan pengolahan data primer yang diperolah dari uji validitas, praktikalitas dan efektifitas (Januarisman and Ghufron 2016).

4. Tahap Penyebaran. Bentuk pelaksanaan yaitu mengupload media web pada salah satu webhosting di internet dan mencobakan media web pada aktivitas perkuliahan mahasiswa baik itu di dalam kelas maupun diluar kelas (Pertiwi and Irfan 2021). Kemudian mempromosikan media pembelajaran berbasis web kepada dosen-dosen dilingkungan Prodi PTI STKIP Muhammadiyah Muara Bungo.

Gambaran lengkap tentang karakteristik atau spesifikasi produk yang diharapkan dari penelitian pengembangan ini adalah sebagai berikut :1) Produk yang dihasilkan adalah media pembelajaran berbasis web berupa perangkat lunak (software) program pembelajaran mata kuliah pemrograman web dasar dalam bentuk website yang terkoneksi dengan jaringan internet (online), dapat dijalankan dengan Mozilla Firefox, Google Chrome atau aplikasi web browser lainnya. 2) Media pembelajaran berbasis web bisa beroperasi atau dijalankan pada komputer, laptop dan smartphone. 3) Desain tampilan media web yang dihasilkan responsive, web akan beradaptasi jika dibuka dari perangkat mobile berukuran kecil maupun perangkat komputer dengan ukuran monitor besar. Bentuk interface (antarmuka pengguna), gambar dan tata letak akan menyesuaikan dengan lebar layar dan resolusi layar monitor yang tersedia. 4) Media diberikan beberapa fasilitas pendukung seperti materi perkuliahan, konten materi dalam bentuk teks dan gambar, video, dan fasilitas download (unduhan) materi perkuliahan. Penggunaan media permbelajaran berbasis web ini dapat mendukung proses pembelajaran di kelas maupun di luar kelas. 5) Terdapat halaman forum diskusi dengan topik pembahasan yang berkaitan dengan materi untuk dosen dan mahasiswa, sehingga dosen dan mahasiswa bisa berinteraksi dan berkomunikasi pada media. 6) Terdapat fitur untuk melakukan pengecekan kode-kode (coding) ketika membuat website. 7) Media yang dikembangkan dapat digunakan oleh mahasiswa kelas dan dosen pada mata kuliah pemrograman web dasar. 
4029 Pengembangan Media Pembelajaran Berbasis Web untuk Meningkatkan Keterampilan Mahasiswa pada Mata Kuliah Pemrograman Web Dasar di STKIP Muhammadiyah Muara Bungo - Yogi Irdes Putra, Ahmad Ridoh

DOI: https://doi.org/10.31004/basicedu.v5i5.1484

\section{HASIL DAN PEMBAHASAN}

Penelitian ini mengembangkan media pembelajaran berbasis web pada mata kuliah pemrograman web dasar di prodi pendidikan teknologi informasi STKIP Muhammadiyah Muara Bungo. Pengembangan media ini dilakukan dengan model pengembangan 4D (fourd- $d$ model), dimana tahap pengembangan media ini yaitu:

1. Tahap Pendefinisian

Pelaksanaan penelitian diawali dengan tahap penentuan (define) bertujuan untuk menetapkan dan mendefinisikan masalah yang dihadapi dalam pembelajaran. Dengan analisis yang dilakukan menghasilkan gambaran fakta, dan alternatif penyelasaian masalah. Pada tahap ini ada 3 hal yang dilakukan yaitu, analisis ujung depan, analisis mahasiswa, dan analisis konsep, dengan uraian sebagai berikut:

a. Analisis Ujung Depan

Tahap ini peneliti melakukan observasi pada mahasiswa Prodi PTI STKIP Muhammadiyah Muara Bungo semester 4. Hal ini untuk mengetahui permasalahan-permasalahan yang mendasar yang ada pada proses pembelajaran Perakitan Komputer. Berdasarkan hasil observasi yang dilakukan, peneliti mendapatkan beberapa informasi mengenai permasalahan yang terjadi selama kegiatan pembelajaran berlangsung. Kenyataannya sebagian mahasiswa masih sulit untuk meningkatkan keterampilan pembuatan website, karena waktu perkuliahan yang disediakan sangat terbatas. Media penunjang yang digunakan yaitu e-learning kampus belum mampu membantu mahasiswa, hal ini karena fitur yang terdapat pada e-learning tersebut masih kurang. Salah satu alternatife media yang bisa digunakan adalah media pembelajaran berbasis web dengan fitur-fitur terbaru yang dikembangkan sesuai kebutuhan mahasiswa seperti adanya video, diskusi grup, simulasi pengkodean web, serta latihan.

Berdasarkan uraian diatas maka penelitian ini dilaksanakan untuk mengembangkan media pembelajaran berbasis web terhadap keterampilan mahasiswa Prodi Pendidikan Teknologi Informasi STKIP Muhammadiyah Muara Bungo pada mata kuliah pemrograman web dasar. Media pembelajaran berbasis web yang akan dikembangkan digunakan sebagai penunjang kegiatan perkuliahan baik dikelas maupun diluar kelas. Media pembelajaran berbasis web yang dihasilkan bersifat online serta memiliki fitur diskusi grup, simulasi dalam pengkodean web, dan dilengkapi dengan video-video materi pembelajaran. Selain itu, hasil penelitian ini dapat dijadikan sebagai referensi dalam mengembangkan media pembelajaran berbasis web.

b. Analisis Mahasiswa

Tahap ini peneliti melakukan observasi untuk mengetahui karakteristik mahasiswa. Karakteristik ini meliputi usia dan kemampuan keterampilan mahasiswa. Usia mahasiswa berkisar antara 20-23 tahun.

Perkembangan kognitif (kemampuan berpikir) pada usia tersebut dijelaskan seperti berikut ini 1) Secara intelektual remaja dapat mulai berpikit logis tentang gagasan abstrak. 2) Berfungsinya kegiatan kognitif tingkat tinggi yaitu membuat rencana, sttrategi, keputusan-keputusan, serta memecahkan masalah. 3) Munculnya kemampuan nalar secara ilmiah, belajar menguji hipotesis. 4) Memikirkan masa depan, perencanaan, dan mengeksplorasi alternative untuk mencapainya psikologi remaja. 5) Wawasan berfikirnya semakin meluas, bisa meliputi agama, keadilan, moralitas, dan identitas (jati diri) (Saputri and Hannah 2018).

Berdasarkan analisis terhadap mahasiswa tersebut, dijadikan pertimbangan dalam pengembangan media web pada mata kuliah pemrograman web dasar. Pengembangan media pembelajaran berbasis web yang dikembangkan telah sesuai dengan kondisi dan karakteristik mahasiswa. Dengan adanya media ini diharapkan mahasiswa dapat lebih mudah memahami materi perkuliahan. 
4030 Pengembangan Media Pembelajaran Berbasis Web untuk Meningkatkan Keterampilan Mahasiswa pada Mata Kuliah Pemrograman Web Dasar di STKIP Muhammadiyah Muara Bungo - Yogi Irdes Putra, Ahmad Ridoh

DOI: https://doi.org/10.31004/basicedu.v5i5.1484

c. Analisis Konsep

Analisis konsep ditujukan untuk mengidentifikasi, menyusun secara sistematis konsep-konsep utama dari materi pada mata kuliah pemrograman web dasar dijadikan sebagai isi media yang akan dikembangkan. Konsep atau materi sangat dipertimbangkan sehingga semua disusun berdasarkan pengetahuan dan keterampilan yang akan dipelajari, dikuasai oleh mahasiswa.

Peneliti perlu mengkaji kurikulum yang berlaku pada saat itu. Dalam kurikulum terdapat capaian pembelajaran yang ingin dicapai. Analisis kurikulum berguna untuk menetapkan pada kompetensi yang mana bahan ajar tersebut akan dikembangkan. Analisis kurikulum bertujuan untuk menetepkan capaian pembelajaran (CP), indikator, dan materi (Divayana, Suyasa, and Sugihartini 2016). Kurikulum yang digunakan berbasis KPT (Kurikulum Pendidikan Tinggi) pada program studi Pendidikan Teknologi Informasi STKIP Muhammadiyah Muara Bungo.

Tabel 1 Analisis Kurikulum.

\begin{tabular}{|c|c|c|}
\hline $\begin{array}{c}\text { CP Prodi (Kompetensi } \\
\text { Inti) }\end{array}$ & Indikator CP MK & Materi \\
\hline \multirow{3}{*}{$\begin{array}{lr}\text { Mampu menerapkan } \\
\text { pemikiran logis, kritis, } \\
\text { sistematis, dan inovatif } \\
\text { dalam } & \text { konteks } \\
\text { pengembangan } & \text { atau } \\
\text { implementasi } & \text { ilmu } \\
\text { pengetahuan dan teknologi } \\
\text { yang memperhatikan dan } \\
\text { menerapkan nilai humaniora } \\
\text { yang sesuai dengan bidang } \\
\text { keahliannya }\end{array}$} & \multirow{3}{*}{$\begin{array}{l}\text { 1. Memiliki } \\
\text { pengembangan ilmu petrampilan } \\
\text { dan teknologi. } \\
\text { 2. Memiliki } \\
\text { implementasi ilmu petrampilan } \\
\text { dan teknologi } \\
\text { 3. Memiliki ketrampilan penalaran } \\
\text { logis dan kritis dalam pemacahan } \\
\text { masalah sesuai dengan bidang } \\
\text { kehalian. } \\
\text { 4. Mampu menghasilkan inovasi } \\
\text { sesai dengan bidang kehalian. }\end{array}$} & $\begin{array}{l}\text { Menggunakan cara membuat } \\
\text { kode perintah pada } H T M L \\
\text { dalam membuat formulir } \\
\text { bekerja dalam sebuah } \\
\text { tampilan web }\end{array}$ \\
\hline & & $\begin{array}{lr}\text { Menggunakan } & \text { cara } \\
\text { penyisipan berbagai } & \text { model } \\
\text { formulir } & \text { dengan } \\
\text { menggunakan kode } & H T M L \\
\text { yang bekerja dalam sebuah } & \text { tampilan (biodata) }\end{array}$ \\
\hline & & $\begin{array}{l}\text { Menggunakan cara membuat } \\
\text { kode perintah pada } H T M L \\
\text { dan CSS bekerja dalam } \\
\text { sebuah tampilan web }\end{array}$ \\
\hline \multirow[t]{3}{*}{$\begin{array}{l}\text { Mahir menggunakan dan } \\
\text { memanfaatkan software } \\
\text { dalam konteks Pendidikan } \\
\text { teknologi informasi }\end{array}$} & \multirow[t]{3}{*}{$\begin{array}{l}\text { 1. Memiliki keterampilan dalam } \\
\text { pengelolaan dan penggunaan } \\
\text { software aplikasi. } \\
\text { 2. Mampu menguasasi berbagai } \\
\text { Bahasa pemrograman. }\end{array}$} & $\begin{array}{l}\text { Menggunakan cara } \\
\text { penyisipan stylesheet dengan } \\
\text { model internal atau eksternal } \\
\text { dengan kode html dan css } \\
\text { bekerja dalam sebuah } \\
\text { tampilan web }\end{array}$ \\
\hline & & $\begin{array}{l}\text { Implementasi } \\
\text { user interface }\end{array}$ \\
\hline & & $\begin{array}{l}\text { Tampilan halaman web } \\
\text { (layout) }\end{array}$ \\
\hline
\end{tabular}

2. Tahap Perancangan

a. Pemilihan Media.

Pemilihan media dilakukan untuk mengidentifikasi media pembelajaran yang tepat untuk menyajikan materi. Media pembelajaran berbasis web dipilih karena penggunaan media ini dapat mengatasi permasalahan yang telah dikemukakan. Media pembelajaran berbasis web dapat memudahkan dosen, karena semua materi bisa dimasukkan ke dalam web dan mahasiswa dengan mudah mengunduhnya. Dengan cara tersebut dapat menghemat waktu, tenaga, biaya. Terjalinnya interaksi antara dosen 
4031 Pengembangan Media Pembelajaran Berbasis Web untuk Meningkatkan Keterampilan Mahasiswa pada Mata Kuliah Pemrograman Web Dasar di STKIP Muhammadiyah Muara Bungo - Yogi Irdes Putra, Ahmad Ridoh

DOI: https://doi.org/10.31004/basicedu.v5i5.1484

dengan mahasiswa tanpa adanya batasan ruang dan waktu dalam penggunaan media web (Herwanto and Febrita 2015). Media pembelajaran berbasis web dapat meningkatkan minat mahasiswa untuk belajar baik itu di kampus dan diluar lingkungan kampus.

b. Rancangan Awal

Membuat rancangan awal media pembelajaran merupakan kegiatan awal dalam pembuatan media, dibagi menjadi 2 tahap yaitu, desain logis (logical design) dan desain fisik (physical design) (Arifa 2021). Hasil desain logis media web pada tahap peracangan awal terdiri dari konsteks diagram. Selanjutnya dilakukan desain fisik (physical design), yaitu pembuatan media berdasarkan rancangan logis dan rancangan fisik awal (Berly, Eril, and Ashabul 2020).

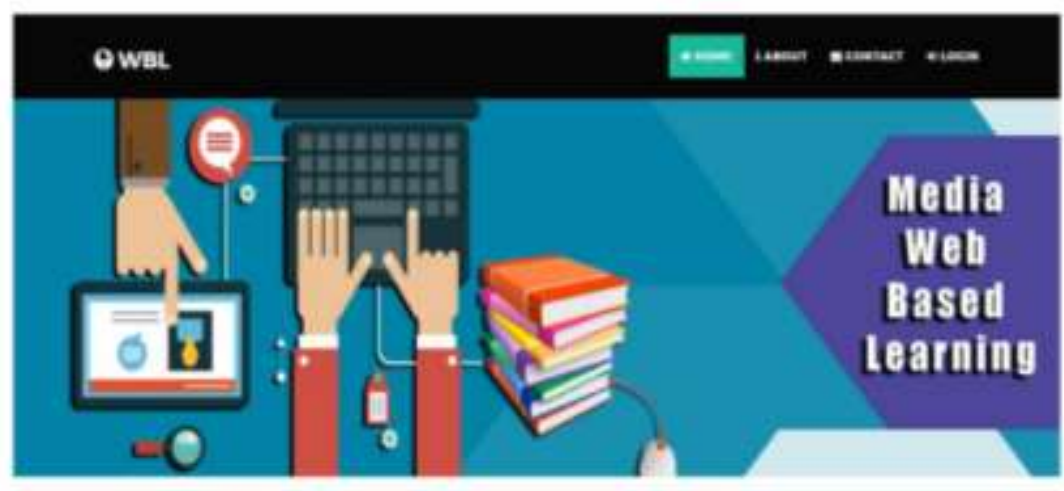

Gambar 1. Tampilan Halaman Utama Media Pembelajaran Berbasis Web

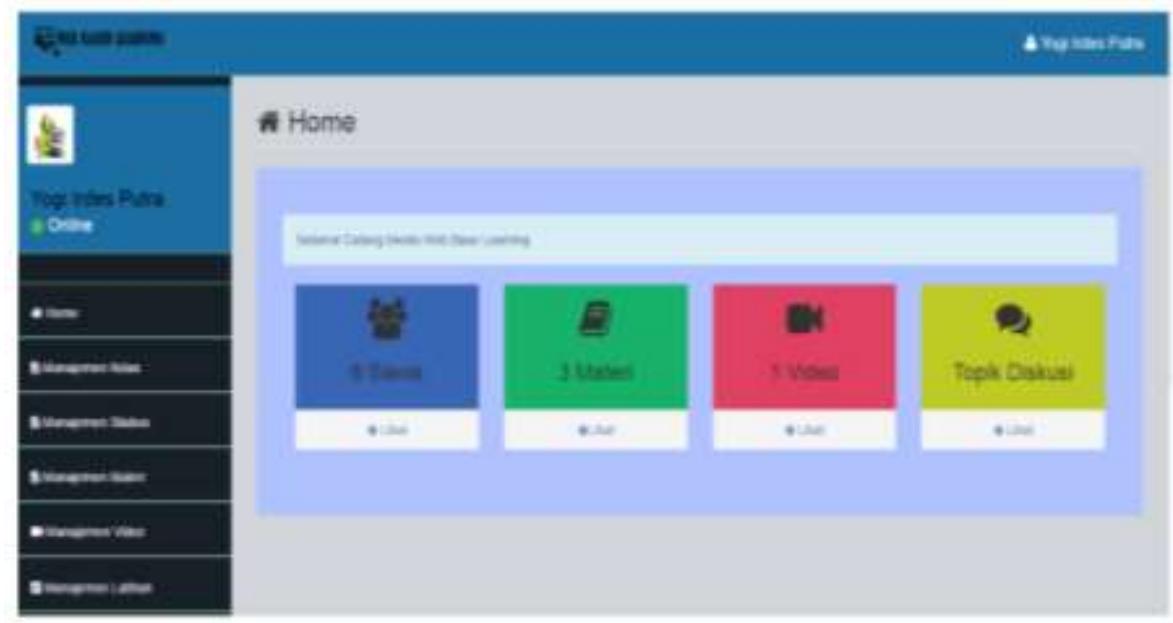

Gambar 2. Tampilan Halaman Utama Dosen 

pada Mata Kuliah Pemrograman Web Dasar di STKIP Muhammadiyah Muara Bungo - Yogi Irdes Putra, Ahmad Ridoh

DOI: https://doi.org/10.31004/basicedu.v5i5.1484

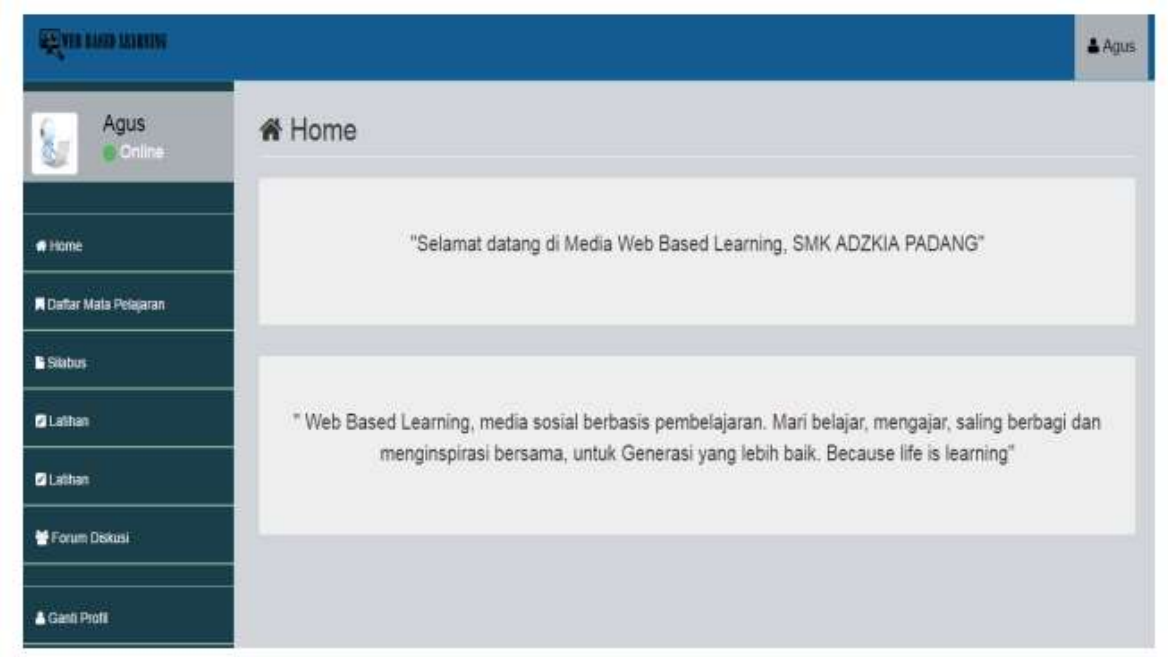

Gambar 3. Tampilan Halaman Utama Mahasiswa

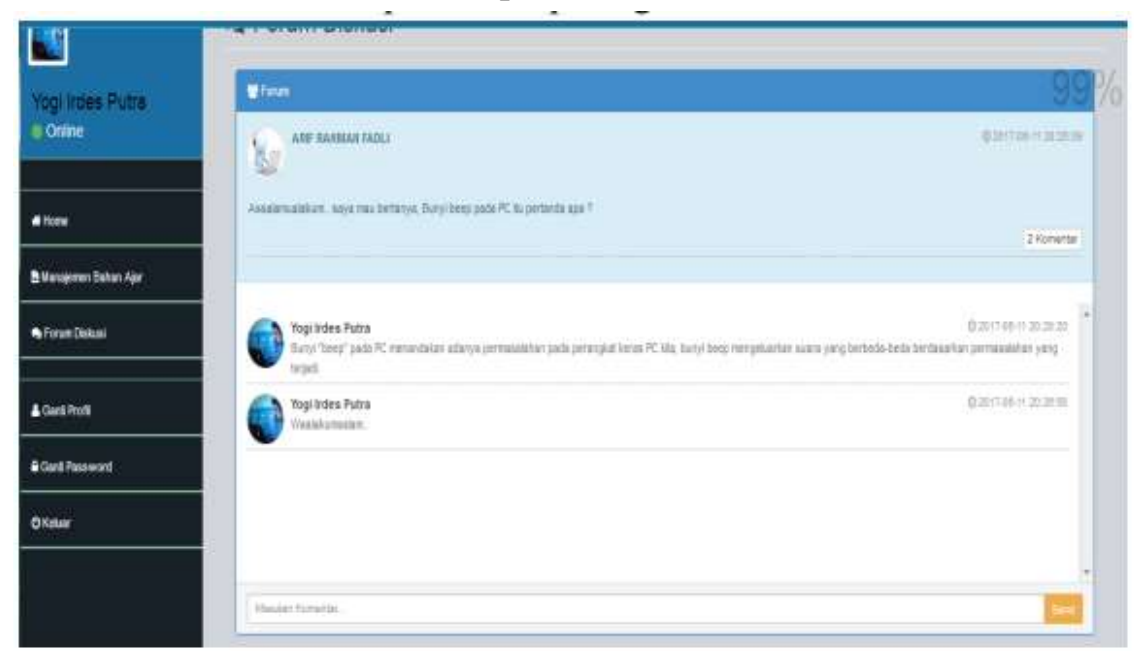

Gambar 4. Tampilan Halaman Forum Diskusi

3. Tahap Pengembangan

Media pembelajaran berbasis web ini telah melalui tahap uji validitas, uji praktikalitas, dan uji efektifitas. Pada uji coba validitas dilakukan dengan cara meminta pendapat kepada validator melalui angket. Dari uji coba validitas yang dilakukan, hasil yang didapat menunjukkan bahwa media pembelajaran berbasis web ini valid digunakan sebagai salah satu alternative media pembelajaran. Uji coba praktikalitas dilakukan dengan meminta pendapat dosen prodi pendidikan teknologi informasi melalui angket. Dari uji coba praktikalitas didapatkan hasil bahwa media pembelajaran berbasis web ini sangat praktis untuk digunakan sebagai salah satu media pembelajaran. Uji coba efektifitas dilakukan dengan cara melihat perbandingan antara tes keterampilan sebelum dan sesudah menggunakan media pembelajaran berbasis web (Efendi and Saragih 2021). Dari uji coba efektifitas yang dilakukan memperoleh hasil bahwa, media pembelajaran berbasis web ini dapat meningkatkan keterampilan mahasiswa. 
4033 Pengembangan Media Pembelajaran Berbasis Web untuk Meningkatkan Keterampilan Mahasiswa pada Mata Kuliah Pemrograman Web Dasar di STKIP Muhammadiyah Muara Bungo - Yogi Irdes Putra, Ahmad Ridoh

DOI: https://doi.org/10.31004/basicedu.v5i5.1484

a. Data Uji Validitas

Aspek validitas yang digunakan antara lain: rekayasa perangkat lunak, komunikasi visual, dan pembelajaran. Hasil penilaian dari masing-masing aspek yang diberikan validator dianalisis menggunakan rumus statistik Aiken"s V (Azwar 2012). Hasil yang didapat merupakan nilai validasi terhadap rancangan produk yang dihasilkan.

Tabel 2. Hasil Validasi Media Web Based Learning oleh Validator.

\begin{tabular}{crcc}
\hline No. & \multicolumn{1}{c}{ Aspek } & Nilai & Kategori \\
\hline 1. & Rekayasa Perangkat Lunak & 0,84 & Valid \\
\hline 2. & Komunikasi Visual & 0,92 & Valid \\
\hline 3. & Pembelajaran & 0,85 & Valid \\
\hline \multicolumn{2}{c}{ Rata-rata } & 0,88 & Valid \\
\hline
\end{tabular}

b. Data Uji Praktikalitas

a. Respon Dosen Terhadap Praktikalitas Media Pembelajaran berbasis Web

Praktikalitas berkaitan dengan kemudahan dalam penggunaaan media yang dikembangkan. Data praktikalitas diperoleh melalui angket yang diisi oleh dua orang praktisi Dosen matakuliah pemrograman web. Hasil penilaian terhadap kepraktisanujian dirangkum pada tabel 3 di bawah ini:

Tabel 3. Rekapitulasi Praktikalitas Berdasarkan Respon Dosen.

\begin{tabular}{|c|c|c|c|c|c|}
\hline \multirow{3}{*}{ No } & \multirow{3}{*}{ Aspek Penilaian } & \multirow{3}{*}{$\begin{array}{c}\text { Persentase } \\
\text { Nilai }\end{array}$} & \multirow{3}{*}{ Kategori } & Persentase & \multirow{3}{*}{ Kategori } \\
\hline & & & & Nilai & \\
\hline & & & & Dosen 2 & \\
\hline \multicolumn{2}{|c|}{ 1. Kualitas isimedia } & $97,14 \%$ & $\begin{array}{l}\text { Sangat } \\
\text { Praktis }\end{array}$ & $88,57 \%$ & Praktis \\
\hline \multicolumn{2}{|c|}{ 2. Daya tarik } & $96,00 \%$ & $\begin{array}{l}\text { Sangat } \\
\text { Praktis }\end{array}$ & $88,00 \%$ & Praktis \\
\hline 3. & $\begin{array}{l}\text { Dapat digunakan sebagai } \\
\text { pembelajaran mandiri }\end{array}$ & $85,00 \%$ & Praktis & $90,00 \%$ & $\begin{array}{l}\text { Sangat } \\
\text { Praktis }\end{array}$ \\
\hline 4. & Efisiensi & $80,00 \%$ & Praktis & $86,67 \%$ & Praktis \\
\hline \multicolumn{2}{|c|}{ Rata-rata praktikalitas respon dosen } & & & & Praktis \\
\hline
\end{tabular}

Tabel 3. didapat rata-rata hasil uji praktikalitas media web menurut dosen yaitu 88,92\%, sehingga dapat disimpulkan media tersebut masuk pada kategori "Praktis".

b. Respon Mahasiswa terhadap Praktikalitas Media Pembelajaran berbasis Web

Praktikalitas media juga memerlukan masukan berupa respon dari mahasiswa. Data ini didapatkan setelah siswa menggunakan media pembelajaran berbasis web, kemudian mahasiswa mengisi dengan angket yang diberikan. Hasil penilaian terhadap kepraktisan media pembelajaran berbasis web dirangkum pada tabel 4.3 di bawah ini :

Tabel 4. Rekapitulasi Praktikalitas Respon Mahasiswa.

\begin{tabular}{rrrr}
\hline No & Aspek Penilaian & Persentase & Kategori \\
\hline 1. & Kemudahan penggunaan media & $87,75 \%$ & Praktis \\
\hline
\end{tabular}


4034 Pengembangan Media Pembelajaran Berbasis Web untuk Meningkatkan Keterampilan Mahasiswa pada Mata Kuliah Pemrograman Web Dasar di STKIP Muhammadiyah Muara Bungo - Yogi Irdes Putra, Ahmad Ridoh

DOI: https://doi.org/10.31004/basicedu.v5i5.1484

\begin{tabular}{clcc}
\hline 2. & Daya tarik & $83,50 \%$ & Praktis \\
\hline 3. & Dapat digunakan sebagai pembelajaran mandiri & $83,33 \%$ & Praktis \\
\hline 4. & Media membantu mahasiswa untuk memahami materi & $82,67 \%$ & Praktis \\
\hline & Rata-rata praktikalitas respon mahasiswa & $84,31 \%$ & Praktis \\
\hline
\end{tabular}

Berdasarkan tabel 3 dan tabel 4, didapat rata-rata hasil uji praktikalitas media pembelajaran berbasis web menurut dosen yaitu $88,92 \%$ dan menurut mahasiswa sebesar $84,31 \%$, sehingga dapat disimpulkan media tersebut masuk pada kategori "Praktis".

c. Data Uji Efektifitas

Efektifitas penggunaan media pembelajaran berbasis web ditinjau dengan melihat ketercapaian kriteria ketuntasan secara klasikal pretest dan posttest.

Ketuntasan klasikal dilihat dari persentase jumlah mahasiswa yang tuntas setelah menggunakan media atau tes akhir. Landasan untuk menentukan efektivitas media web adalah jika persentasi ketuntasan klasikal mahasiswa lebih besar atau sama dengan $85 \%$ maka media pembelajaran berbasis web efektif digunakan. Jika sebaliknya, maka media web tidak efektif digunakan. Berikut hasil rata-rata nilai ketuntasan klasikal pretest dan posttest mahasiswa pada mata kuliah pemrograman web dasar.

Tabel 5. Hasil Analisis Klasikal Nilai Pretest.

\begin{tabular}{|c|c|c|c|c|c|c|c|}
\hline \multirow[b]{2}{*}{ No } & \multirow[b]{2}{*}{ JumlahMahasiswa } & \multirow[b]{2}{*}{ Nilai Maksimum } & \multirow[b]{2}{*}{$\begin{array}{c}\text { Nilai } \\
\text { Minimum }\end{array}$} & \multicolumn{4}{|c|}{ Rentang Nilai } \\
\hline & & & & $\begin{array}{c}<75 \\
\text { (Tidak } \\
\text { Tuntas) }\end{array}$ & $\%$ & $\begin{array}{c}\geq 75 \\
\text { (Tuntas) }\end{array}$ & $\%$ \\
\hline 1 & 20 & 96 & 60 & 7 & 35 & 13 & 65 \\
\hline
\end{tabular}

Tabel 6. Hasil Analisis Klasikal Nilai Postest .

\begin{tabular}{|c|c|c|c|c|c|c|c|}
\hline \multirow[b]{2}{*}{ No } & \multirow[b]{2}{*}{ JumlahMahasiswa } & \multirow[b]{2}{*}{ Nilai Maksimum } & \multirow[b]{2}{*}{$\begin{array}{c}\text { Nilai } \\
\text { Minimum }\end{array}$} & \multicolumn{4}{|c|}{ Rentang Nilai } \\
\hline & & & & $\begin{array}{c}<75 \\
\text { (Tidak } \\
\text { Tuntas) }\end{array}$ & $\%$ & $\begin{array}{c}\geq 75 \\
\text { (Tuntas) }\end{array}$ & $\%$ \\
\hline 1 & 20 & 92 & 68 & 3 & 15 & 17 & 85 \\
\hline
\end{tabular}

Berdasarkan hasil analisis klasikal nilai pretest yang diuraikan pada tabel 5, maka diperoleh jumlah mahasiswa yang tuntas sebanyak 13 mahasiswa (65\%), sedangkan hasil analisis klasikal nilai posttest yang diuraikan pada tabel 6 diperoleh jumlah mahasiswa yang tuntas sebanyak 17 mahasiswa (85\%), hal ini menunjukkan ketuntasan klasikal telah tercapai. Dapat disumpulkan bahwa media pembelajaran berbasis web pada matakuliah pemrograman web dasar efektif digunakan jika ditinjau dari ketuntasan klasikal.

4. Tahap Penyebaran

Bentuk pelaksanaan tahap penyebaran yaitu mengupload media pembelajaran berbasis web pada salah satu webhosting di internet dan mencobakan media web pada aktivitas perkuliahan mahasiswa baik itu di dalam kelas maupun diluar kelas. Kemudian mempromosikan media pembelajaran berbasis web kepada dosen-dosen dilingkungan Prodi PTI STKIP Muhammadiyah Muara Bungo. 


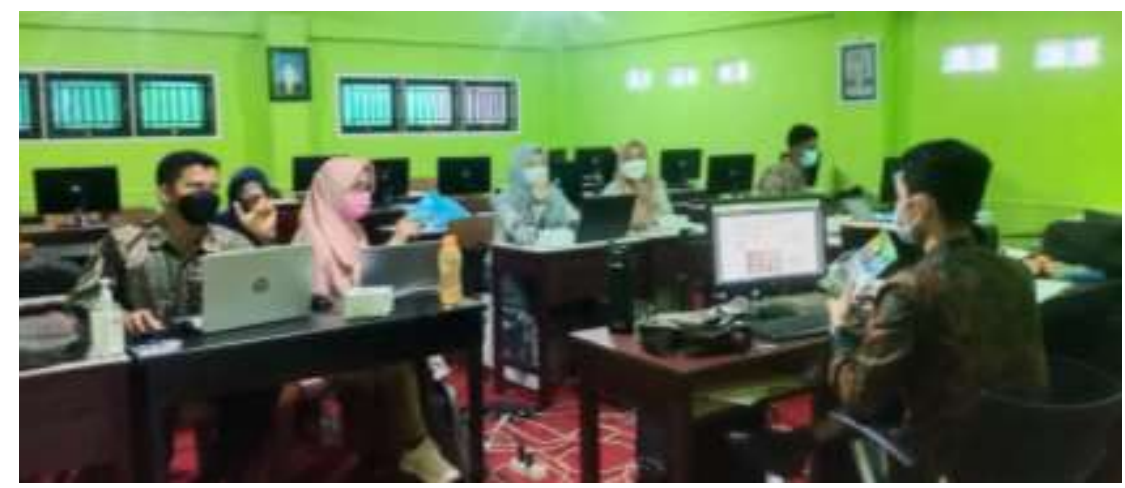

Gambar 5. Mempromosikan Media Pembelajaran berbasis Web dengan Dosen-Dosen.

\section{KESIMPULAN}

Berdasarkan hasil penelitian pengembangan media web based learning pada mata pelajaran Perakitan Komputer di kelas X TKJ SMK Adzkia Padang yang telah dilakukan, maka diperoleh kesimpulan sebagai berikut : 1. Penelitian ini termasuk jenis penelitian Research and Development $(R \& D)$. Prosedur pengembangan penelitian ini mengacu pada model pengembangan 4-D (four-d models). 4-D terdiri dari 4 tahapan pengembangan, yaitu (1) Define (pendefinisian), dilakukan untuk mendeskripsikan permasalahan dan menganalisis kebutuhan serta kondisi, mencakup analisis ujung depan, analisis mahasiswa, dan analisis konsep. (2) Design (perancangan), yaitu mempersiapkan dan membuat media yang dikembangkan. (3) Develop (pengembangan), dilakukan untuk menghasilkan media pembelajaran berbasis web yang valid, praktis, dan efektif berdasarkan masukan dari pakar serta uji coba media. (4) Disseminate (penyebaran), Bentuk pelaksanaan yaitu mengupload media pembelajaran berbasis web pada salah satu webhosting di internet dan mencobakan media web pada aktivitas perkuliahan mahasiswa baik itu di dalam kelas maupun diluar kelas. Kemudian mempromosikan media pembelajaran berbasis web kepada dosen-dosen dilingkungan Prodi PTI STKIP Muhammadiyah Muara Bungo. 2. Hasil penelitian pengembangan media pembelajaran berbasis web, diperoleh berdasarkan hasil uji pengembangan. Uji pengembangan meliputi uji validitas, uji praktikalitas dan uji efektifitas. Uji validitas dinilai oleh validator dari 3 aspek dengan perolehan nilai sebesar 0,84 (aspek rekayasa perangkat lunak), 0,92 (aspek komunikasi visual), 0,88 (aspek pembelajaran), maka dapat dikatakan media pembelajaran berbasis web Valid. Uji praktikalitas diperoleh dari penilaian respon dosen sebesar 88,92\% dengan kategori "Praktis" dan respon mahasiswa sebesar 84,31\% dengan kategori "Praktis". Hasil uji efektifitas media media pembelajaran berbasis web diperoleh dari hasil belajar praktik mahasiswa yang mencapai kriteria ketuntasan $85 \%$ secara klasikal. Dengan demikian, maka media ini memiliki akurasi yang tinnggi berdasarkan hasil uji kelayakan.

\section{DAFTAR PUSTAKA}

Arifa, Evina Fuadiya. 2021. "Pengembangan Media Pembelajaran Berbasis Web Pada Mata Pelajaran Pemrograman Web Paket Keahlian Multimedia Kelas X Di Smk Nasional Malang.” Skripsi Mahasiswa $U m$.

Azwar, Saifuddin. 2012. "Reliabilitas Dan Validitas." Yogyakarta: Pustaka Pelajar.

Berly, Roza, Syahmadi Eril, And Khairi Ashabul. 2020. "Pengembangan Media Pembelajaran Berbasis Web Pada Mata Pelajaran Komputer Dan Jaringan Dasar.” Universitas Bung Hatta. 
4036 Pengembangan Media Pembelajaran Berbasis Web untuk Meningkatkan Keterampilan Mahasiswa pada Mata Kuliah Pemrograman Web Dasar di STKIP Muhammadiyah Muara Bungo - Yogi Irdes Putra, Ahmad Ridoh

DOI: https://doi.org/10.31004/basicedu.v5i5.1484

Darmansyah, Darmansyah. 2010. "Pembelajaran Berbasis Web: Teori, Konsep Dan Aplikasi."

Darmawiguna, I Gede Mahendra. 2013. "Media Pembelajaran Berbasis Web Dan Flash Untuk Mata Kuliah Riset Operasi Di Jurusan Pti, Undiksha." Jst (Jurnal Sains Dan Teknologi) 2 (1).

Daryanto, Drs. 2013. "Media Pembelajaran Peranannya Sangat Penting Dalam Mencapai Tujuan Pembelajaran." Gava Media.

Divayana, Dewa Gede Hendra, P Wayan Arta Suyasa, And Nyoman Sugihartini. 2016. "Pengembangan Media Pembelajaran Berbasis Web Untuk Matakuliah Kurikulum Dan Pengajaran Di Jurusan Pendidikan Teknik Informatika Universitas Pendidikan Ganesha." Jurnal Nasional Pendidikan Teknik Informatika: Janapati 5 (3): 149-57.

Efendi, Aldino, And Saut Pintubipar Saragih. 2021. "Pengembangan Media Pembelajaran Berbasis Web Pada Materi Pemograman Web Di Kota Batam.” Computer And Science Industrial Engineering (Comasie) 4 (4): 43-51.

Herwanto, Heru Wahyu, And Ruth Ema Febrita. 2015. "Pengembangan Media Pembelajaran Berbasis Web Pada Matakuliah Pemrograman Berorientasi Objek.” Tekno 21 (1).

Januarisman, Erwin, And Anik Ghufron. 2016. "Pengembangan Media Pembelajaran Berbasis Web Mata Pelajaran Ilmu Pengetahuan Alam Untuk Siswa Kelas Vii.” Jurnal Inovasi Teknologi Pendidikan 3 (2): $166-82$.

Muhammad Hakiki. 2021. "Perancangan Sistem Informasi Manajemen Berbasis Sekolah Sma Negeri 1 Muara Bungo." Muara Pendidikan 6. Http://Ejournal.Stkip-Mmb.Ac.Id/Index.Php/Mp/Article/View/513.

Pertiwi, Elsa, And Dedy Irfan. 2021. "Pengembangan Media Pembelajaran Berbasis Web Pada Mata Pelajaran Sistem Komputer Kelas X Tkj Di Smk Negeri 1 Painan.” Intecoms: Journal Of Information Technology And Computer Science 4 (2): 202-8.

Pratomo, Adi, And Agus Irawan. 2015. "Pengembangan Media Pembelajaran Interaktif Berbasis Web Menggunakan Metode Hannafin Dan Peck.” Positif 1 (1): 159673.

Putra, Yogi Irdes. 2017. "Pengembangan Media Web Based Learning Pada Mata Pelajaran Perakitan Komputer Kelas X Tkj Smk Adzkia Padang.” Universitas Negeri Padang.

Rukun, Kasman, And Dedy Irfan. 2020. "Website-Based Learning Media Development For Computer And Basic Network.” In Progress In Social Science, Humanities And Education Research Symposium, 57-61. Redwhite Press.

Rusman, Deni Kurniawan, And Cepi Riyana. 2011. "Pembelajaran Berbasis Teknologi Informasi Dan Komunikasi." Bandung: Rajawali Pers.

Rusman, M Pd, And Riyana Cepi. 2012. "Belajar Dan Pembelajaran Berbasis Komputer." Bandung: Alfabeta.

Saputri, Nurul Adha Oktarini, And Merriayu Puspita Hannah. 2018. "Analisis Efektifitas Penggunaan WebBased-Learning Pada Matakuliah Praktikum Struktur Data." Just It: Jurnal Sistem Informasi, Teknologi Informasi Dan Komputer 8 (2): 69-75.

Sugiyono, Prof Dr. 2010. "Metode Penelitian Pendidikan.” Pendekatan Kuantitatif. 